УДК 347

DOI https://doi.org/10.32837/pyuv.v0i1(30).513

\author{
В. М. Марченко \\ orcid.org/0000-0003-0788-4649 \\ президент \\ Нотаріальної палати України
}

\title{
ОКРЕМІ ПИТАННЯ ВПРОВАДЖЕННЯ В УКРАЇНІ СИСТЕМИ Е-НОТАРІАТУ
}

Цифрові технології займають важливу роль у сучасному житті. Вони все більше знаходять застосування у і правовій сфері. У статті досліджуються питання використання цифрових технологій у нотаріальному процесі і напрями реформування чинного законодавства в цій сфері.

Питання електронного нотаріату (далі - E-нотаріату) та електронних правочинів є досить актуальним, і їх дослідженням присвячувалися роботи таких фахівців як С.Я. Фурса, О. Кирилюк, О.М. Криштопа, Н.Є. Блажівська, А. Волков та інших.

Варто зазначити, що особливо відчутною стала необхідність активнішого використання електронних технологій в часи кризи, пов'язаної з поширенням пандемії коронавірусу COVID-19. Так, під час дії карантину значна кількість людей у тих сферах, де це можливо, перейшла на віддалену від офісу роботу, а бізнес активніше застосовує електронні технології у комунікації та співпраці, зокрема при укладенні договорів.

Серед відносин, в яких досить активно застосовуються електронні технології в Україні, варто назвати банківську сферу. У більшості банків функціонують електронні сервіси, які дозволяють віддалено, без відвідування банківських офісів здійснювати необхідні операції. Зокрема, Національний банк планує підвищити частку безготівкових розрахунків платіжними картками до кінця 2020 року до $55 \%$ із поточних $50 \%$ [1].

Також все активніше застосовуються електронні технології у судовій системі. Зокрема, на проведенні засідань в режимі відеоконференції акцентована увага в листі Ради суддів України від 16.03.2020 № 9pc-186/20 [2]. Варто зазначити, що проведення відеоконференцій передбачене чинним процесуальним законодавством з 2012 року, тому такий крок є цілком виваженим з огляду на наявну ситуацію.

В цьому випадку можна говорити про активніше застосування практики проведення відеоконференцій у судочинстві, адже, починаючи з 2016 року, практика відеоконференцій набрала обертів і технічно була реалізована в більшості судів, а за 2018 рік в Україні було проведено 73500 відеоконференцій [3]. Тому можна стверджувати, що знадобилося досить багато часу для впровадження механізму відеоконференцій у судовий процес. 3 урахуванням того, що суди роз- глядають близько 800000 справ за один квартал [4], відсоток відеоконференцій у судовому процесі не є значним.

Запровадження електронних технологій робить простішим і зручнішим товарообіг, використання послуг чи доступ до інформації. Так, Постановою Кабінету Міністрів України від 15.04.2020 № 278 «Про реалізацію експериментального проєкту щодо застосування відображення в електронному вигляді інформації, яка міститься в паспорті громадянина України у формі картки, та відображення в електронному вигляді інформації, що міститься у паспорті громадянина України для виїзду за кордон» передбачено можливість пред'явлення E-nacnopma та E-nаспорта для виїзду за кордон (відображення в електронному вигляді інформації, яка міститься у відповідному паспорті) за допомогою вебпорталу електронних послуг «Портал Дія» протягом періоду реалізації експериментального проєкту замість паспорта громадянина України та паспорта громадянина України для виїзду за кордон. Такий крок є зручним для громадян і спрощує систему ідентифікації фізичних осіб у сферах, визначених постановою, до яких не належить ідентифікація осіб для вчинення нотаріальних дій, адже ці відносини врегульовані спеціальним законодавством.

Варто наголосити, що процес впровадження електронних технологій має бути виваженим і насамперед передбачати достатній захист інформації. Якщо вести мову про Е-нотаріат, то варто зазначити, що це поняття є комплексним і охоплює різні сфери професійної діяльності нотаріуса. Нині в нотаріальній діяльності досить активно використовуються можливості електронних технологій, зокрема для здійснення професійної діяльності нотаріуси мають доступ до Єдиного реєстру нотаріусів, Єдиного реєстру спеціальних бланків нотаріальних документів, Державного реєстру обтяжень рухомого майна, Спадкового реєстру, Єдиного реєстру довіреностей, Державного реєстру речових прав на нерухоме майно, Державного реєстру актів цивільного стану громадян, Єдиного державного реєстру юридичних осіб, фізичних осіб-підприємців та громадських формувань. Однак Е-нотаріат передбачає комплексне застосування електронних технологій. Зокрема, обов'язковим складником вказаного поняття є електронний реєстр нотаріальних дій. 
Наприклад, у Грузії, де електронний реєстр нотаріальних дій Нотаріальної палати діє з 2009 року, доступ до нього здійснюють за визначеними параметрами, реквізитами нотаріального акту - індивідуальним унікальним номером і номером реєстрації в електронному реєстрі. Будьякий громадянин може перевірити факти реєстрації в електронному реєстрі нотаріальних дій, які його стосуються, а також факти реєстрації у електронному нотаріальному реєстрі акту, який був ним представлений [5].

Оптимальним варіантом для функціонування E-нотаріату має бути узгоджена робота електронного реєстру нотаріальних дій з іншими електронними реєстрами та сервісами, які застосовуються при вчиненні нотаріальної дії. Так, у Республіці Казахстан єдина нотаріальна інформаційна система дозволяє нотаріусам проводити перевірку документів і визначати статус громадян через державні бази даних. При цьому передбачається обов'язковість електронного цифрового підпису у нотаріусів, а також ведення електронного реєстру «Е-нотаріат» [6].

$\mathrm{У}$ європейських країнах застосування електронних підписів та електронних систем обміну інформацією в нотаріальній діяльності є досить поширеним явищем. Зокрема, у Франції функціонує спеціальна мережа, до якої підключені нотаріальні відділення, завдяки чому нотаріуси мають змогу обмінюватися необхідною інформацією між собою і з третіми сторонами, мати доступ до внутрішніх і публічних баз даних, пропонувати послуги із застосуванням електронного підпису, а також до мережі європейської бази даних, зокрема про заповіти, та до документів європейського нотаріату [7, с. 532].

В Італії нотаріуси використовують електронні інструменти за допомогою спеціалізованої IT-компанії «Нотартель», створеної в 1997 році Національною радою нотаріусів Італії, якою забезпечується функціонування Єдиної нотаріальної мережі. За допомогою цієї мережі було досягнуто комп'ютеризації процесів оформлення нотаріальних документів, документообігу, а також доступу до інформації, необхідної нотаріусам при вчиненні нотаріальних дій, зокрема усіх публічних реєстрів і внесення до них змін за наслідками вчинених нотаріальних дій $[8$, с. 89].

Електронні технології також активно застосовуються в діяльності нотаріусів у ФРН. Зокрема, це стосується роботи з електронними реєстрами та використання електронного документообігу. В Німеччині нотаріуси використовують електронні картки підпису (кваліфікований електронний підпис), які випускаються Федеральною нотаріальною палатою, причому не лише для нотаріусів, а й для адвокатів та інших суб’єктів [9, с. 17].

Поруч 3 іншими європейськими країнами, в яких електронні технології в діяльності нотарі- ату використовуються протягом досить тривалого часу, одним із лідерів у цій сфері стає Естонія, яка комплексно впроваджує електронні технології, в тому числі в нотаріат.

З огляду на досвід інших країн, запровадження Е-нотаріату є необхідною передумовою стабільного розвитку системи нотаріату. Зокрема, Нотаріальною палатою України (далі - НПУ) в 2017 році була оприлюднена Концепція реформування нотаріату в Україні, складником якої є впровадження Е-нотаріату. 3 цього приводу О. Кирилюк слушно зауважує, що запровадження електронного нотаріату відповідає етапам державної політики, закріпленим у Законі «Про Національну програму інформатизації», згідно з ч. 3 ст. 2 якого національна програма інформатизації формується з урахуванням довгострокових пріоритетів соціально-економічного, науково-технічного, національно-культурного розвитку країни, світових напрямів розвитку та досягнень у сфері інформатизації і спрямовується на розв'язання найважливіших загальносуспільних проблем (забезпечення розвитку освіти, науки, культури, охорони довкілля та здоров'я людини, державного управління, національної безпеки, оборони держави та демократизації суспільства) та створення умов для інтеграції України у світовий інформаційний простір відповідно до сучасних тенденцій інформаційної геополітики [10].

Створенню Концепції, яка в подальшому лягла в основу співпраці з Міністерством юстиції, передувала кропітка робота нотаріусів над проблемами, які існують у нотаріальному процесі та професійному самоврядуванні. Концепція спрямована на оновлення та доповнення розвитку сучасного українського нотаріату, а також на децентралізацію структури нотаріальних органів 3 метою надання якісних послуг правового характеру та вчинення нотаріальних дій відповідно до міжнародних стандартів. Серед іншого вона передбачає й впровадження Е-нотаріату. В рамках співпраці між НПУ та Міністерством юстиції України (далі - Мін'юст) було розроблено законопроект, спрямований на реформування нотаріату.

Як зазначає очільник Мін'юсту Д. Малюська, найближчим часом в України має відбутися перехід до електронного нотаріату, зокрема нотаріуси зможуть завіряти електронні документи. В разі, якщо Верховна Рада України зможе прийняти розроблений законопроєкт протягом декількох місяців, робоча система електронного нотаріату 3'явиться до кінця поточного року [11].

Варто зауважити, що електронний реєстр нотаріальних дій згідно з міжнародними стандартами і практикою країн латинського нотаріату розробляє та впроваджує професійна самоврядна організація, якою в України є НПУ. Одним із найважливіших питань в рамках запровадження 
Е-нотаріату $є$ узгодження роботи електронного реєстру нотаріальних дій, інших реєстрів та баз даних, які використовуються при вчиненні нотаріальних дій. При цьому необхідно виправити всі технічні недосконалості таких реєстрів, які досить часто виявляються у нотаріальній практиці.

Запровадження Е-нотаріату слугуватиме досягненню відразу декількох цілей. Це допоможе нівелювати корупційні ризики, адже головна мотивація для запровадження змін - технологічно спростити фізичним та юридичним особам процес здійснення ними суб'єктивних прав в рамках вчинення нотаріальних дій, покращити рівень захисту таких прав. При цьому буде спрощено як порядок вчинення нотаріальних дій і зберігання та пошук інформації в нотаріальному архіві, так і обмін відповідною інформацією в разі потреби.

Важливо наголосити, що значення реєстру вчинених нотаріальних дій полягає у підтвердженні вчинення нотаріальної дії, захисті інформації про вчинені нотаріальні дії та унеможливленні зміни чи підробки відповідних відомостей. Традиційно реєстри ведуться в паперовій формі, що у поєднанні зі спеціальними вимогами законодавства до порядку ведення реєстрів для реєстрації нотаріальних дій становило надійне джерело зберігання інформації. Однак розвиток технологій призводить до відмови від паперових носіїв інформації в різних сферах суспільного життя. Це стосується й фондового ринку, де більшість цінних паперів мають бездокументарну (електронну) форму, банківської сфери, торгівлі тощо. У зв'язку з цим можна стверджувати, що існує досить технічних можливостей перейти 3 паперового на електронний реєстр нотаріальних дій.

Створення єдиного реєстру нотаріальних дій дозволить оптимізувати роботу нотаріусів, адже відмова від паперових архівів та перехід на електронний формат можуть значно спростити роботу нотаріусу. Однак головним наслідком впровадження електронного реєстру будуть позитивні зміни в процесі вчинення нотаріальної дії та захисті прав осіб, які звернулися за тї вчиненням. Зокрема, вчинення нотаріальної дії триватиме швидше, адже інформація, необхідна для їі вчинення, буде перевірятися простіше і надійніше. Крім того, в подальшому учасникам правочину чи особам, які звернулися за вчиненням нотаріальної дії, буде простіше отримувати необхідні документи (копії), а в деяких випадках це можна буде зробити самостійно за допомогою електронного цифрового підпису.

В рамках новелізації нотаріального законодавства Е-нотаріат розглядається як єдина інформаційно-телекомунікаційна система, призначена для збору, накопичення, обробки, зберігання, захисту та використання відомостей щодо нотаріальної діяльності та забезпечення всіх видів інформаційної взаємодії (обміну). Вказана система призначена для накопичення відомостей про вчинені нотаріальні дії, відомостей і примірників документів, поданих у паперовій формі, або документів в електронній формі, на підставі яких вчиняються нотаріальні дії та інші відомості, передбачені законодавством. При цьому програмне забезпечення системи Е-нотаріату повинно надавати можливість електронної інформаційної взаємодії в режимі реального часу з електронними інформаційними системами та мережами, які становлять державні інформаційні бази (реєстри), інформаційні ресурси органів місцевого самоврядування, інших суб'єктів надання інформації, необхідних для вчинення нотаріальних дій і здійснення нотаріальної діяльності.

Передбачається, що після набрання чинності змін до законодавства про нотаріат існуватиме можливість ведення реєстру для реєстрації нотаріальних дій у паперовій формі та/або в електронній формі, а з часом усі нотаріуси перейдуть на використання електронного реєстру з огляду на істотні переваги в його використанні.

Серед інших аспектів застосування електронних технологій у нотаріальному процесі слід вказати на розширення можливостей нотаріуса щодо посвідчення електронних правочинів чи посвідчення електронних копій документів. Зокрема, серед розроблених спільно НПУ i Мін'юстом пропозицій до чинного законодавства пропонується доповнити процесуальне законодавство положеннями про можливість використання електронних копій довіреностей. Передбачається, що електронна копія нотаріально посвідченої довіреності, виготовлена нотаріусом, який її посвідчив, з використанням кваліфікованого електронного підпису нотаріуса може бути подана в електронній формі.

Також пропонується доповнити ст. 58 Закону «Про нотаріат» нормою, згідно з якою за бажанням особи, яка звернулася за посвідченням довіреності, нотаріус додатково виготовляє їі електронну копію з використанням кваліфікованого електронного підпису нотаріуса одночасно з вчиненням нотаріальної дії у порядку, визначеному законодавством. Оскільки електронний документообіг з використанням ключів захисту набуває все більшого застосування, такі пропозиції допоможуть спростити підтвердження повноважень повіреного на представництво інтересів без формальних ускладнень, пов'язаних із необхідністю надавати паперовий екземпляр довіреності.

Крім того, одним із перспективних напрямів розвитку нотаріату є посвідчення нотаріусом за допомогою електронного підпису електронних договорів, коли сам договір укладатиметься шляхом узгодження волі контрагентів і підписуватиметься електронними підписами сторін і нотаріуса. 
Питання запровадження Е-нотаріату є вкрай актуальним. Нотаріуси мають достатній досвід діяльності з електронними реєстрами, і практика їх використання свідчить про істотні переваги такого процесу. Нотаріальна спільнота та фахівці з нотаріального процесу неодноразово наголошували на необхідності якнайшвидшого запровадження в життя Е-нотаріату.

3 вказаного питання існує багато практичних напрацювань, в тому числі з урахуванням іноземного досвіду. Переваги Е-нотаріату стосуються всіх аспектів нотаріального процесу і передбачають як оптимізацію діяльності нотаріуса, так і пришвидшення порядку вчинення нотаріальної дії, захисту прав її учасників. Впровадження Е-нотаріату матиме комплексний позитивний ефект, який виявиться у спрощенні порядку вчинення нотаріальних дій, а також зберіганні та обміні інформацією про вчинені нотаріальні дії.

Основнамета електронного нотаріату-незвести функції нотаріуса до механічних, а зробити нотаріат максимально доступним і зручним для осіб, які звертаються за вчиненням нотаріальних дій. Враховуючи активну співпрацю між НПУ і Мін'юстом у питанні реформування нотаріату, є всі підстави сподіватися на те, що запровадження системи Е-нотаріату буде здійснено у найкоротші строки.

\section{Jimepamypa}

1. Частка безготівкових розрахунків до кінця 2020 року складе $55 \%$ - НБУ. URL: https://minfin.com.ua/ ua/2019/11/29/39874773/.

2. Рада суддів рекомендуе запровадити особливий режим роботи судів України. Юрліга. URL: https://jurliga.ligazakon.net/ua/news/193778_radasuddv-rekomendu-zaprovaditi-osobliviy-rezhim-robotisudv-ukrani.

3. Сафip Ф. Історія судових відеоконференцій в Україні. Юридична газета. № 19(673). URL: https://yur-gazeta.com/publications/practice/sudovapraktika/istoriya-sudovih-videokonferenciy-v-ukrayini. html.

4. Інформація про розгляд місцевими та апеляційними судами судових справ і матеріалів за I квартал 2017 року. URL: https://court.gov.ua/userfiles/ image/1205/1 2017.pdf.

5. Куценко С. Е-реєстр прискорить оформлення майна. HB. URL:https://nv.ua/ukr/biz/experts/e-reyestrpriskorit-oformlennya-mayna-1757808.html.

6. Савченко А. Электронноебудущее нотариатав Казахстане. Profit. URL: https://profit.kz/news/6085/ Elektronnoe-buduschee-notariata-v-Kazahstane/.

7. Теорія нотаріального процесу : Науково-практичний посібник / За заг. ред. С.Я. Фурси. Київ : Алерта; Центр учбової літератури, 2012.920 с.

8. Бернацька I. Нотаріат Італії - огляд, доступ до професії, технології, відчуження нерухомості та Національна рада нотаріусів. MEH. № 6(78), 2014. С. 86-93.

9. Реформування нотаріату за стандартами ЄС: саморегулювання, Е-нотаріат. Нотаріат України. № 4(35), 2019. C. $16-19$.

10. О. Кирилюк. Посвідчення електронних правочинів може стати реальністю за умови законодавчих змін. Закон і бізнес. URL: https://zib.com.ua/ua/ 132119-e-notariat mozhe stati realnistyu za umovi zakonodavchih zmi.html.

11. Денис Малюська: Електронна система нотаріату може бути запущена до кінця 2020 року. URL: https://minjust.gov.ua/news/ministry/denis-malyuskaelektronna-sistema-notariatu-moje-buti-zapuschena-dokintsya-2020-roku.

\section{Анотація}

Марченко В. М. Окремі питання впровадження в Україні системи Е-нотаріату. - Стаття.

У статті досліджуються питання впровадження в Україні системи Е-нотаріату. Застосування електронних технологій набуває все більшого поширення в різних сферах суспільного життя. Вказані технології дозволяють спростити і зробити надійнішим i безпечнішим товарообіг, надання послуг чи доступ до інформації. Цей процес стосується і правової сфери. Зокрема, вказані технології активно застосовуються в банківській сфері, на фондовому ринку, в судовій системі.

Нотаріат також активно використовує наявні електронні бази даних, зокрема Єдині і Державні реєстри. Як свідчить іноземний досвід, саме запровадження Е-нотаріату зможе кардинально покращити ситуацію в цій сфері і стати необхідною передумовою стабільного розвитку системи нотаріату. У статті вказано на успіхи запровадження E-нотаріату в багатьох країнах системи латинського нотаріату.

Одним із важливих складників Е-нотаріату $€$ запровадження електронного реєстру нотаріальних дій і нотаріального архіву. При цьому електронний реєстр має бути інтегрований з наявними базами даних (реєстрами), які використовуються в нотаріальному процесі. Електронний реєстр нотаріальних дій згідно 3 міжнародними стандартами та практикою країн латинського нотаріату розробляє та впроваджує професійна самоврядна організація, якою в України є Нотаріальна палата України. Вказані кроки дозволять вчиняти нотаріальні дії у спрощеному порядку. При цьому головною перевагою буде простіший пошук відомостей, необхідних для вчинення нотаріальної дії, більша достовірність отримуваної інформації та надійніший іï̈ захист.

Іншим аспектом Е-нотаріату є закріплення можливостей посвідчення нотаріусами електронних правочинів, копій електронних документів тощо. Цей аспект діяльності давно затребуваний у сфері сучасного цивільного обороту. Нотаріальна палата України у співпраці з Міністерством юстиції України активно розробляє проєкти нормативних актів, спрямованих на реформування нотаріату, зокрема і запровадження Е-нотаріату. В разі успішного втілення відповідних законопроєктів у життя, система Е-нотаріату зможе запрацювати найближчим часом.

Ключові слова: Е-нотаріат, електронний правочин, електронний підпис, електронні реєстри.

\section{Summary}

Marchenko V. M. Some issues of implementation of the E-notary system in Ukraine. - Article.

The article explores the issues of implementation of the E-notary system in Ukraine. The use of electronic technologies is becoming more widespread in various spheres of public life. These technologies make it easier and more reliable to trade, provide services or access to information. This process also applies to the legal sphere. These technologies are actively used in the banking sector, the stock market, and the judicial system. The notary is also actively applying real-time electronic databases, 
including the United and State Registers. As evidenced by the foreign experience of using of E-notary system, this step is a prerequisite for the stable development of the notary system.

In particular, the article highlights the success of the introduction of the E-notary in many countries of the Latin notary system. One of the important components of an E-notary is the introduction of an electronic register of notarial acts and a notarial archive. The electronic register must be integrated with the existing databases (registers) used in the notarial process. An electronic register of notarial acts in accordance with international standards and practices of Latin notary countries is developed and implemented by a professional self-governing organization, which in Ukraine is the Notary Chamber of Ukraine.
These steps will allow to take notarial actions in a simplified manner. The main advantage will be a simpler search for the information needed to commit a notarial act, greater reliability of the information received and more secure protection. Another aspect of the E-notary is securing the possibility of notarizing electronic transactions, making copies of electronic documents, etc. This aspect of activity has long been in demand in modern life.

The Notary Chamber of Ukraine in cooperation with the Ministry of Justice of Ukraine is actively developing draft normative acts aimed at notary reform and in particular the introduction of the E-notary. If the relevant bills are successfully implemented, the E-notary system will be able to work soon.

Key words: E-notary, electronic signature, electronic registers. 